\title{
Perancangan Sistem E-voting berbasis Web untuk Ketua Himpunan Mahasiswa Teknologi Rekayasa Perangkat Lunak
}

\author{
Nurhidayat Subagio \\ Teknologi Rekayasa Perangkat \\ Lunak \\ Politeknik Pertanian Negeri \\ Samarinda \\ Samarinda \\ dayat.subagio@gmail.com
}

\author{
Wahyuni Eka Sari \\ Teknologi Rekayasa Perangkat \\ Lunak \\ Politeknik Pertanian Negeri \\ Samarinda \\ Samarinda \\ wahyunisari52@gmail.com
}

\author{
Yulianto \\ Teknologi Rekayasa Perangkat \\ Lunak Politeknik Pertanian Negeri \\ Samarinda \\ Samarinda \\ yulianto.tile@yahoo.com
}

\begin{abstract}
Abstrak - Penelitian ini di latar belakangi dengan kemajuan teknologi yang mempermudah dalam pemilihan dengan meminimalisirkan anggaran pengeluaran kertas dan konsumsi secara berlebih dalam acara pemilihan ketua himpunan mahasiswa yang selama ini dilakukan secara manual. Oleh karena itu penulis bertujuan membangun sebuah sistem E-voting pemilihan ketua himpunan mahasiswa teknologi rekayasa perangkat lunak agar mempermudah dalam melakukan pemilhan dan meminimalisirkan waktu efesinsi produktifitas Belajar mahasiswa di dalam kampus dan mengurangi hasil surat suara rusak.
\end{abstract}

Kata Kunci - e-voting, webiste, himpunan mahasiswa

\section{PENDAHULUAN}

Pemilihan umum merupakan bagian pada suatu proses demokrasi. Indonesia adalah salah satu negara demokrasi yang melaksanakan pemilihan umum setiap 5 tahun sekali. Di indonesia, pelaksanaan pemilihan umum dilakukan mulai dari tingkat desa, kota, bupati, DPRD tingkat 2, gubernur dan anggota DPRD 1), sampai tingkat pemerintah pusat yaitu Presiden, dan untuk organisasi mahasiswa di universitas tinggi atau pun sekolah tinggi pemilhan ketua organisasi juga di lakukan dengan cara pemilihan.

Pemilihan umum di Indonesia masih dilakukan secara manual. Warga atau masyarakat mempunyai hak voting atau hak pilih untuk setiap calon pemimpin yang ada, hak pilih hanya berlaku untuk satu pemimpin yang dipilih. Mereka terbiasa memilih pemimpin dengan cara datang ketempat pemilihan dan mendapatkan surat suara yang diperoleh dari panitia lalu warga mencontreng ditempat yang telah disediakan $(\sqrt{ })$ lalu menaruh atau memasukan ke kotak suara yang telah disediakan. Proses pemungutan suara selesai kemudian dilakukan perhitungan suara.

Proses pemungutan dan perhitungan suara secara konvensional tersebut mempunyai beberapa kelemahan antara lain :

1. Lambatnya proses perhitungan suara di Indonesia, proses penghitungan suara biasanya membutuhkan waktu yang sangat lama
2. Sering munculnya perdebatan mengenai sah atau tidaknya sebuah kertas suara

3. Tidak ada salinan terhadap kertas suara yang telah dipilih untuk membuktikan benar atau tidaknya surat suara yang rusak

4. Menghambat kinerja

5. Besarnya anggaran yang dilakukan untuk melakukan proses pemungutan suara. Berdasarkan data terakhir KPU (Komisi Pemilihan Umum), yaitu lembaga pemerintaha yang bertugas melakukan pelaksanaan pemilihan umum di Indonesia, pemerintah telah menyetujui anggaran pemilu mencapai Rp 10,4 triliun untuk pelaksanaan pemilihan umum tahun 2009 sampai dengan tahun 2014, anggaran sebsar itu di gunakan

Hasil dalam penelitian aplikasi Sistem e-voting ini dapat memberikan informasi hasil dari pemilihan ketua himpunan mahasiswa dan mahasiswa dapat memilih pasangan calon yang diinginkan. untuk mencetak kertas suara, gaji panitia dan lain lain.

Dengan adanya permasalahan tersebut tercipta lah gagasan untuk memanfaatkan perkembangan teknologi yang ada, khususnya berbasis web. Pemilihan suara secara elektronik dengan memanfaatkan teknologi elektronik (e-Voting) saat ini dapat menjadi salah satu alternatif untuk menggantikan pemilihan umum secara konvensional yang sekarang ini digunakan. penelitian tentang e-Voting telah dilakukan lebih dari 20 tahun dengan permasalahan keamanaan, sampai saat ini belum ada solusi lengkap baik secara teori maupun praktik yang mengatasi permasalahan tersebut.

\section{TINJAUAN PUSTAKA}

\section{A. Studi Literatur}

Beberapa literatur yang digunakan sebagai pedoman dan acuan dalam Tugas Akhir ini antara lain :

1. Pada penelitian yang dilakukan oleh Muhammad salehudin, (2009) Yang berjudul pembuatan model e-Voting berbasis web (studi kasus pemilu legislative dan presiden Indonesia). Dengan tujuan mengimplementasikan pemrograman sql dan php. 
2. Pada penelitian yang dilakukan oleh Dede subhan, (2009) Yang berjudul system e-Voting berbasis web. Dengan tujuan mempercepat pengumpulan hasil suara.

3. Pada penelitian yang dilakukan oleh A. Murtado, (2011) Yang berjudul aplikasi pemilihan ketua badan eksekutif mahasiswa STMIK Pontianak berbasis dekstop. Dengan tujuan membantu badan eksekutif mahasiswa memilih ketua dan mengimplementasikan voting yang terkomputerisasi

4. Pada penelitian yang dilakukan oleh Aditya wari nugroho, (2012) Yang berjudul perancangan eVoting berbasis web (studi kasus pemilihan kepala daerah sukoharjo). Dengan tujuan mengurangi adanya konflik antar peroleh hasil perhitungan suara.

5. Pada penelitian yang dilakukan oleh Nani purwati, (2015) Yang berjudul perancangan system e-Voting untuk pemilihan kepala daerah. Dengan tujuan mengurangi adanya kecurangan jual beli surat suara

Tabel 1. Studi Literatur

\begin{tabular}{|c|c|c|c|}
\hline No & Nama/Tahun & Judul & $\begin{array}{l}\text { Perbedasn dengan } \\
\text { penelitian yang terdshulu }\end{array}$ \\
\hline 1 & $\begin{array}{l}\text { Muhammad } \\
\text { Salehudin, } \\
\text { (2009) }\end{array}$ & $\begin{array}{l}\text { Pembuatan Model } \\
\text { E-Voting Berbasis } \\
\text { Web (studi kasus } \\
\text { pemilu legislative } \\
\text { dan presiden } \\
\text { Indonesia). }\end{array}$ & $\begin{array}{l}\text { Mengimplementasikgn } \\
\text { bahasa pemrograman php } \\
\text { dan sql dalam pemilihan } \\
\text { presiden }\end{array}$ \\
\hline 2 & $\begin{array}{l}\text { Dede } \\
\text { Subhan, } \\
(2009)\end{array}$ & $\begin{array}{l}\text { System E-Voting } \\
\text { Berbasis Web. }\end{array}$ & $\begin{array}{l}\text { Dengan tujuan } \\
\text { mempercepat pengumpulan } \\
\text { hasil suara. }\end{array}$ \\
\hline 3 & $\begin{array}{l}\text { A. Murtado, } \\
\text { (2011) }\end{array}$ & $\begin{array}{l}\text { Aplikasi Pemilihan } \\
\text { Ketua Badan } \\
\text { Eksekutif Mahasiswa } \\
\text { STMIK Pontianak } \\
\text { Berbasis Dekstop. }\end{array}$ & $\begin{array}{l}\text { membantu badan eksekutif } \\
\text { mahasiswa memilih ketua } \\
\text { dan mengimplementasikan } \\
\text { voting } \\
\text { vang terkomputerisasi. }\end{array}$ \\
\hline 4 & $\begin{array}{l}\text { Nani } \\
\text { Punwati, } \\
\text { (2015) }\end{array}$ & $\begin{array}{l}\text { Perancangan } \\
\text { System E-Voting } \\
\text { Untuk Pemilihan } \\
\text { Kepala Daerah }\end{array}$ & $\begin{array}{l}\text { mengurangi adanya } \\
\text { kecurangan jusl beli surat } \\
\text { suara }\end{array}$ \\
\hline 5 & $\begin{array}{l}\text { Nurul } \\
\text { Azwanti } \\
\text { (2017) }\end{array}$ & $\begin{array}{l}\text { Perancangan } \\
\text { E-Voting Berbasis } \\
\text { Web }\end{array}$ & $\begin{array}{l}\text { Sistem aplikasi ini di buat } \\
\text { untuk keperluan pemilihan } \\
\text { ketua rukun tetangga } \\
\text { dengantujuan } \\
\text { pengimplementasikan } \\
\text { tekhnologi di dalam } \\
\text { pemilihan }\end{array}$ \\
\hline
\end{tabular}

\section{1) Dasar Teori Demokrasi}

Demokrasi berasal dari bahasa yunani yang diambil dari kata demokratia yang berarti "kekuasaan rakyat". Demokratria sendiri terdiri dari dua kata yakini demor yang asrtinya "rakyat" dan kratos yang mempunyai arti "kekuasaan atau kekuatan" (salamadian,2012).

Secara umum pengertian demokrasi adalah bentuk pemerintahan yang setiap warga Negara mempunyai yang setara dalam pengambilan sesuatu keputusan yang akan memberikan efek dalam kehidupan mereka. Demokrasi juga bisa diartikan kekuasaan tertinggi di tangan rakyat

\section{2) Pemilihan Umum (Pemilu)}

Pemilihan Umum (Pemilu) atau dalam bahasa inggris disebut election adalah cara yang digunakan untuk mewujudkan partisipasi rakyat dalam pemerintahan sebagai pemegang kekuasaan tertinggi. Pemilihan umum sudah menjadi bagian yang tidak terpisahkan dari suatu negara demokrasi, hampir semua negara demokrasi melaksanakan pemilihan umum (Salehudin, M. 2009).

Pemilihan umum adalah proses pemilihan wakil rakyat di parlemen dan kepala pemerintahan berdasarkan suara terbanyak. Mantan sekretaris jenderal PBB (Perserikatan Bangsa-Bangsa) atau UN (United Nations) pernah mengatakan bahwa pemilihan umum merupakan elemen utama dari demokrasi sebagai sebuah cara masyarakat untuk mengambil keputusan .

Di Indonesia, Pemilu merupakan bagian yang sangat penting dalam kegiatan bernegara. Peraturan tertinggi mengenai pemilu diatur dalam Undang-Undang Dasar (UUD) 1945 hasil amandemen. Pemilu secara tegas diatur pada UUD 1945 perubahan III, bab VIIB tentang Pemilihan Umum, pasal 22E. Berikut ini adalah isi pasal tersebut.

a. Pemilihan umum dilaksanakan secara langsung, umum, bebas, rahasia, jujur, dan adil setiap lima tahun sekali.

b. Pemilihan umum diselenggarakan untuk memilih anggota Dewan Perwakilan Rakyat, Dewan Perwakilan Daerah, Presiden dan Wakil Presiden dan Dewan Perwakilan Rakyat Daerah.

c. Peserta pemilihan umum untuk memilih anggota Dewan Perwakilan Rakyat dan anggota Dewan Perwakilan Rakyat Daerah adalah partai politik.

d. Peserta pemilihan umum untuk memilih anggota Dewan Perwakilan Daerah adalah perseorangan.

e. Pemilihan umum diselenggarakan oleh suatu komisi pemilihan umum yang bersifat nasional, tetap, dan mandiri.

f. Ketentuan lebih lanjut tentang pemilihan umum diatur dengan undang-undang

\section{3) Pengertian e-Voting}

Pengertian dari electronic voting (e-Voting) secara umum adalah penggunaan teknologi komputer pada pelaksanaan voting. menjelaskan secara umum sejarah, jenis Electronic Voting, keuntungan dan kerugian dalam penggunaannya. Pilihan teknologi yang digunakan dalam implementasi dari e-Voting sangat bervariasi, seperti penggunaan smart card untuk otentikasi pemilih, penggunaan internet sebagai sistem pemungutan suara, penggunaan touch screen 
sebagai pengganti kartu suara, dan masih banyak variasi teknologi yang digunakan (Purwati, N. 2015).

Adapun Negara-negara yang telah berhasil menerapkan Sistem e-Voting, sebagai berikut:

a) Kanada

Kanada telah menerapkan sistem $e$-voting sejak tahun 1990-an. Negara dengan ibukota Ottawa ini sudah mencoba optical scan voting dan internet voting.

Untuk pemilihan dalam tingkat negara dan provinsi, mereka masih menggunakan optical scan voting, karena jumlah suara yang dihitung lebih banyak dan kompleks. Sedangkan internet voting biasa diterapkan pada pemilihan tingkat kota.

Pada pemilihan umum tahun 2012, sistem $e$ voting Kanada sempat diserang oleh hacker. Namun, ini tidak membuat Kanada mundur, mereka tetap melakukan $e$-Voting hingga pemilihan terakhir mereka di tahun 2017.

b) Estonia

Negara kecil yang terletak di Benua Eropa ini sudah mulai menggunakan internet voting sejak tahun 2005 dalam taraf lokal. Kemudian di tahun 2007, mereka meningkatkannya menjadi taraf nasional.

Sistem yang diterapkan Estonia sudah cukup maju. Semua penduduknya memiliki smart ID cardyang berfungsi untuk mencegah pemilih ganda. Meskipun begitu, beberapa masalah juga muncul. Di antaranya adalah masalah sekuritas dan kurangnya pengawasan dalam hal privasi.

voting di Estonia bisa dibilang berhasil. Sistem ini mampu merangkul berbagai kalangan dan memberikan kemudahan akses memilih untuk. Warga Estonia yang berada di luar negeri juga bisa mengakses internet voting. Estonia kini terus mengembangkan teknologi $e$-Voting mereka untuk meminimalisasi kendala yang berpotensi terjadi.

c) Fillipina

e-Voting di Filipina dapat dikatakan berhasil. Negara tetangga ini sudah menerapkan evoting secara nasional sejak tahun 2010. Langkah ini diambil oleh Filipina untuk mengatasi kecurangan dalam pemilihan umum.

Teknologi yang dipakai negara kepulauan ini disebut dengan Automated Election System (AES). Cara kerja mesin tersebut sama dengan optical scan voting, yaitu untuk menghitung suara dengan lebih cepat melalui scanning kertas suara.

E-voting disambut baik oleh penduduk Filipina. Partisipasi pemilih pun meningkat. Pada pemilihan umum tahun 2016, partisipasi penduduk Filipina mencapai angka lebih dari 80 persen. Keberhasilan Filipina dalam mengembangkan sistem e-voting pun menuai perhatian dunia.

4) Himpunan Mahasiswa Jurusan (HMJ)

HMJ adalah kependekan dari Himpunan Mahasiswa Jurusan. Yang merupakan wadah bagi mahasiswamahasiswa jurusan untuk dapat berkumpul dan mengadakan kegiatan bersama dilingkup jurusan tertentu. Himpunan Mahasiswa Jurusan (HMJ) merupakan suatu lembaga organisasi ditingkat jurusan yang berperan melaksanakan kegiatan kemahasiswaan dilingkungan jurusan. Program kerja yang dilaksanaka HMJ disesuikan dengan bidang kajian atau keilmuan yang ada di masing-masing jurusan. HMJ berperan sebagai sarana pengembangan minat-bakat, penalaran dan keilmuan bagi mahasiswa di masing-masing jurusan.Badan permusyawarahan desa

5) $\mathrm{Web}$

Website adalah kumpulan dari berbagai macam halaman situs, yang terangkum di dalam sebuah domain atau juga subdomain, yang lebih tepatnya berada di dalam word wide web $(w w w)$ yang tercantum terdapat di dalam internet. Halaman website biasanya berupa dokumen yang di tulis dengan format hyper text markup language (html), yang bisa di akses melalui http, http adalah suatu protocol yang menyampaikan berbagai informasi dari server website untuk di tampilkan kepada para user (Muis, A. 1990).

Menurut garis besar website dapat dikelompokkan menjadi 3 jenis yaitu:

a. Web Statis adalah website yang memiliki halaman tidak berubah. Yaitu untuk melakukan pergantian disuatu halaman dilakukan dengan cara manual dengan mengedit code sebagai struktur dari web itu.

b. Web Dinamis adalah website yang secara terstruktur diperuntukan untuk update sesering mungkin. Umumnya selain yang paling penting dapat dibuka oleh user biasa, juga sudah disiapkan halaman backend untuk mengedit content dari situs. Misalnya yaitu web portal berita atau situs portal yang didalamnya ada sarana berita, polling, dsb.

c. Web Interaktif adalah website yang sekarang ini sangat booming. Salah satu contoh web interaktif yaitu situs (blog) serta forum. Di situs ini user dapat berhubungan serta beradu pendapat tentang pemikiran mereka. Umumnya situs seperti ini mempunyai moderator untuk mengatur agar tema yang diperbincangkan tidak keluar jalur.

\section{6) Domain}

Sublime Text adalah aplikasi editor untuk kode dan teks yang dapat berjalan diberbagai platform operating system dengan menggunakan teknologi Phyton API. Terciptanya aplikasi ini terinspirasi dari aplikasi Vim,

Aplikasi ini sangatlahfleksibel dan powerfull. Fungsio nalitas dari aplikasi ini dapat dikembangkandengan meng gunakan sublimpackages. Sublime Text bukanlah aplik asi opensource dan juga aplikasi yang dapat digunakan dan didapatkan secara gratis, akan tetapi beberapa fitur pengembangan fungsionalitas ( $p a$ ckages) dari aplikasi ini merupakan hasil dari temuan dan mendapat dukungan penuh dari komunitas serta memiliki linsensi aplikasi gratis. 


\section{7) HTML (Hypertext Markup Language)}

Menurut Hidayatullah dan Kawistara (2014) HTML (Hypertext Markup Laguage) adalah bahasa standar yang digunakan untuk menampilkan halaman web

\section{8) PHP (PHP: Hypertext Processor)}

PHP adalah singktan dari "PHP: Hypertext Processor", yaitu bahasa pemrograman yang digunakan secara luas untuk penanganan pembuatan dan pengembangan sebuah situs web dan bisa digunakan bersamaan dengan HTML. PHP diciptakan oleh Ramus Lerdorf pertama kali tahun 1994. Pada awalnya PHP adalah "Personal Home Page Tools". Selanjutnya diganti menjadi FI (Forms Interpreter). Sejak versi 3.0, nama bahasa ini diubah menjadi "PHP: Hypertext Prepocessor" dengan singkatannya "PHP".

Pada Juni 2004, Zend merilis PHP 5.0. Dalam versi ini, inti dari interpreter PHP mengalami perubahan perubahan besar. Versi ini juga memasukkan model pemrograman berorientasi objek ke dalam PHP untuk menjawab perkembangan bahasa pemrograman ke arah paradigma berorientasi objek.

PHP dapat dijalankan melalui file HTML yang kemudian dipanggil melalui Web Browser seperti Mozilla Firefox, Netscape, atau Internet Explorer. Program dalam PHP ditulis dengan diberi ekstensi '.php' (Rasjid, 2014).

\section{9) JavaScripts}

JavaScript adalah bahasa scripting yang popular di internet dan dapat bekerja di sebagian besar browser popoler seperti Internet Explorer (IE), Mozila Firefox, Netscape dan Opera. Kode Javascript dapat disisipkan dalam halaman web menggunakan tag SCRIPT (Sunyoto, 2007).

\section{METODE PENELITIAN}

Before you begin to format your paper, first write and save the content as a separate text file. Complete all content and organizational editing before formatting. Please note sections A-D below for more information on proofreading, spelling and grammar.

\section{1) Tempat dan Waktu}

Penelitian yang telah dilakukan ditempatkan di Politeknik Negri Pertanian Negeri Samarinda. Penelitian yang dilakukan ini akan memakan waktu selama 6 bulan yaitu bulan Oktober 2018 - April 2019 dengan alur penyusunan data dan dilanjutkan pembuatan aplikasi dan penyusunan laporan .

2) Alat dan Bahan

Alat yang digunakan dalam penelitian ini adalah meliputi:

1. Acer Aspire f5-672g

2. Processor intel(R) core $(\mathrm{tm})$ i3-6006U cpu@ 2.00Ghz 4(CPUs), $2.0 \mathrm{GHz}$

3. XAMPP

4. PHP

5. Sublime Text

6. Browser Google

\section{3) Prosedur Penelitian}

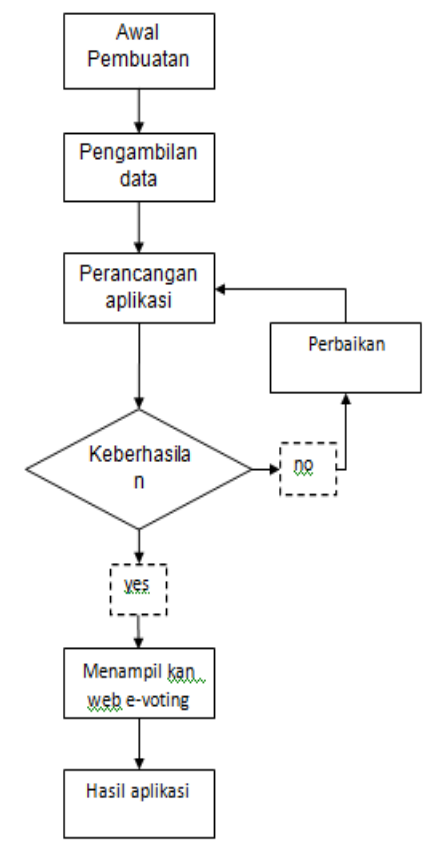

Gambar 1 Prosedur Penelitian

\section{B. Perancangan aplikasi}

Penjelasan pengerjaan sistem yang dilakukan adalah untuk membuat suatu aplikasi. e-Voting pemilihan Ketua Himpunan Mahasiswa Teknologi Rekayasa Perangkat Lunak berbasis web. Dengan pengambilan data real dan pengamatan di Program Studi Teknologi Rekayasa Perangkat Lunak.

Ada pun table yang di sertakan dalam perancangan aplikasi berupa:

1) Tb_user

Fungsi dari table ini adalah untuk menyimpan data data user yang telah diinputkan oleh admin agar from login mengetahi sapa saja yang boleh masuk, dan mengetahui apakah dia user atau admin jika from login menggunakan user maka masuk ke Aplikasi e-Voting Pemilihan Ketua Himpunan Mahasiswa dan jika from login atas admin maka akan masuk ke aplikasi admin. Admin memiliki hak ases berulang kali terhadap tampilan aplikasi admin.

Tabel 1. Login

\begin{tabular}{ll}
\hline Nama Field & tipe data \\
\hline user.id & $\operatorname{int}(11)$ \\
username & $\operatorname{varchar}(200)$ \\
password & $\operatorname{varchar}(200)$ \\
Status & varchar(200) \\
Admin_user & varchar(15) \\
\hline
\end{tabular}


2) Tb_Paslon

Fungsi dari table paslon adalah menginput atau menghapus atau mengupdate data dari pasangan yang ingin mencalon kan diri nya menjadi ketua Himpunan Mahasiswa dan mempermudah admin untuk mengetahui dari kandidat pasangan yang mengikuti pemilihan

Tabel 2. nama_calon

\begin{tabular}{ll}
\hline Nama Field & tipe data \\
\hline Id & $\operatorname{int}(11)$ \\
nama & $\operatorname{varchar}(50)$ \\
foto & $\operatorname{varchar}(50)$ \\
Visi_misi & $\operatorname{varchar}(255)$ \\
value & $\operatorname{varchar}(200)$ \\
\hline
\end{tabular}

3) Tb_hasil

Table hasil adalah table yang menampilkan hasil pemilihan atau tempat pemilihan berlangsung.

Tabel 3. hasil

\begin{tabular}{ll}
\hline Nama Field & tipe data \\
\hline id & int(11) \\
Php_framework & varchar(100) \\
\hline
\end{tabular}

\section{Rancangan User Interface}

\section{Rancangan menu utama}

Menu utama adalah tampilan yang menampilkan halaman awal pada aplikasi saat masuk dari from login, dari menu utama terdapat fitur yang dapat di pilih oleh user pada saat masuk tampilan utama akan menampilkan halaman Pemilihan di tampilan ini user bisa langsung memilih pasangan calon yang diinginkan, halaman beranda terdapat informasi mengenai himpunan mahasiswa, tampilan data calon dimana user dapat melihat visi misi dan tujuan calon menjadi kandidat, halaman progresbar menampilkan tampilan keuser presentase hasil polling, halaman logout keluar dari aplikasi e-Voting dan jika

user logout tanpa memilih maka akun user masih bisa untuk login kembali untuk melakukan pemilihan.

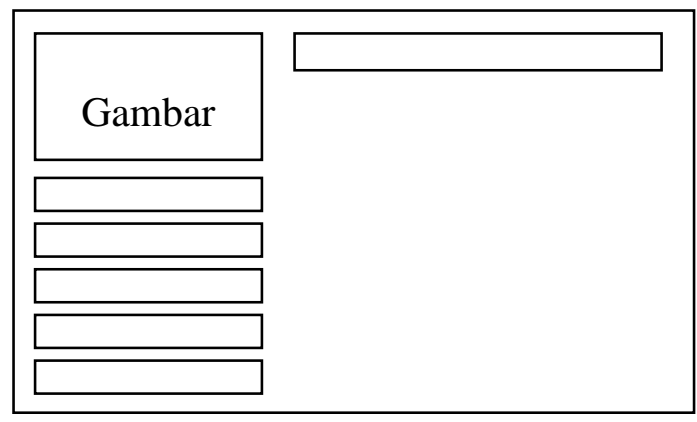

\section{Rancangan Menu Voting}

Pada menu ini dirancang agar user dapat menggunakan hak pilih untuk memilih pasangan calon yang ingin dipilih, ketika user telah menentukan pilihan pasangan calon desa maka klik tombol save maka akan menyimpan dan tak bisa digagalkan. Dan jika user menekan button save maka localhost akan menampilkan penjelasan bahwa anda harus memilih terlebih dahulu. kesempatan user memilih hanya 1 suara setiap memilih, fungsi dari ini adalah agar user tidak bisa memilih kedua kali dan aplikasi ini dapat melihat tujuan utama dari pasangan calon yang mendaftarkan untuk menjadi ketua Himpunan Mahasiswa. Pada menu ini dirancang agar user dapat mudah memahami prosedur penggunaan aplikasi .

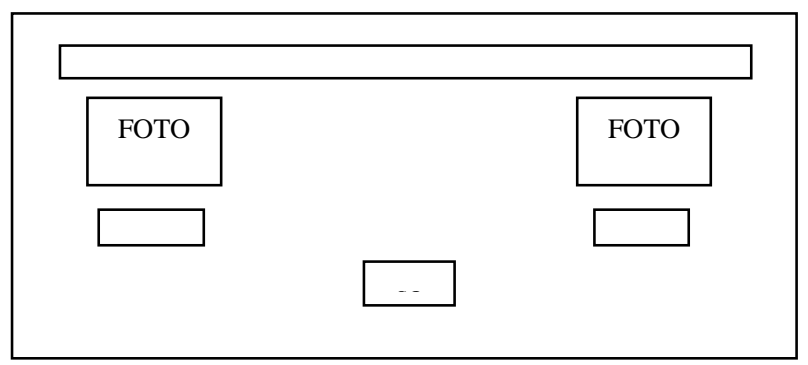

Gambar 2. Rancangan Menu Voting

\section{Rancangan Menu Login}

Pada tampilan login digunakan oleh user dan admin agar user dan admin atau pengguna dapat masuk kehalaman yang telah di atur dari aplikasi web voting, didalam halaman ini user atau pengguna diminta memasukan username dan password, user name dan password ini didapatkan dari no NIM dan usernamenya adalah nama dari pengguna. Setelah username dan password telah diinput user dapat menekan button atau tombol login untuk mulai masuk ketampilan halaman utama dari aplikasi voting. ketika username menekan tombol atau button login sebelum menginputnya maka akan tetap berada dihalaman login. Dan jika salah dalam memasukan password atau username maka halaman akan tetap berada didalam login . sama halnya dengan admin bedanya hanya admin akan masuk ketampilan admin yang sudah disediakan

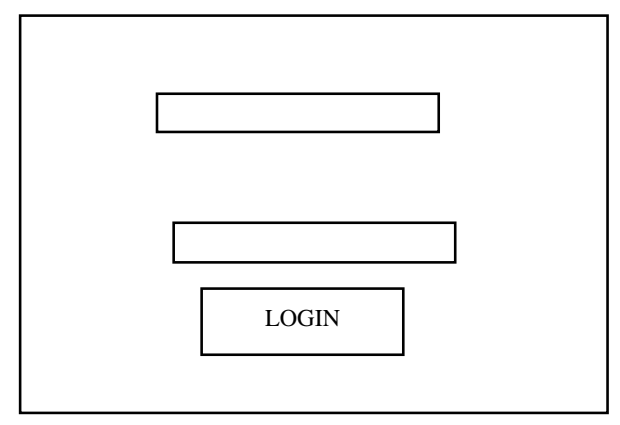

Gambar 3. Rancangan Menu Login

Gambar 1. Rancangan Menu Utama 


\section{Rancangan Menu Data Calon}

Menu Data Calon ini akan menampilkan visi dan misi dari pasangan calon dengan adanya menu ini user dapat mengetahui pasangan calon yang akan dipilih dari keterangan program kerjanya.

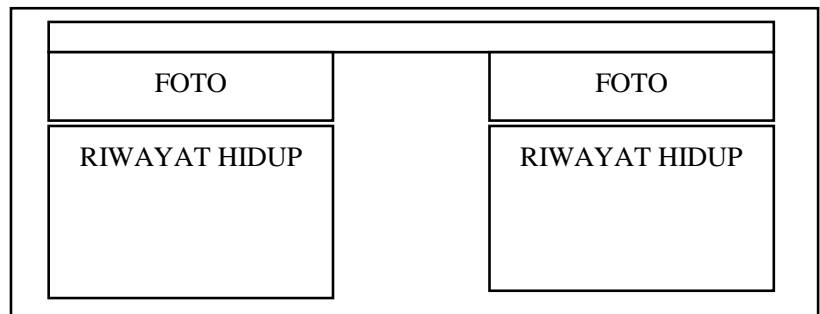

Gambar 4. Rancangan Menu Data Calon

\section{HASIL DAN PEMBAHASAN}

\section{A. Hasil Pembuatan Aplikasi}

\section{Tampilan Login}

Pada halaman awal mengakses Aplikasi e-Voting ini menampilkan from login dalam from login ini user atau pengguna dapat menginputkan nama sesuai KTM(Kartu Tanda Mahasiswa) dan nim sesuai ktm agar masuk ke Aplikasi e-Voting, dan difrom login ini juga admin masuk dengan menggunakan nama dan nim sesuai ktm . ketika nama dan nim salah maka tampilan akan tetap menjadi from login, jika benar nama dan nim maka akan kemenu aplikasi. Dapat dilihat pada gambar 7.

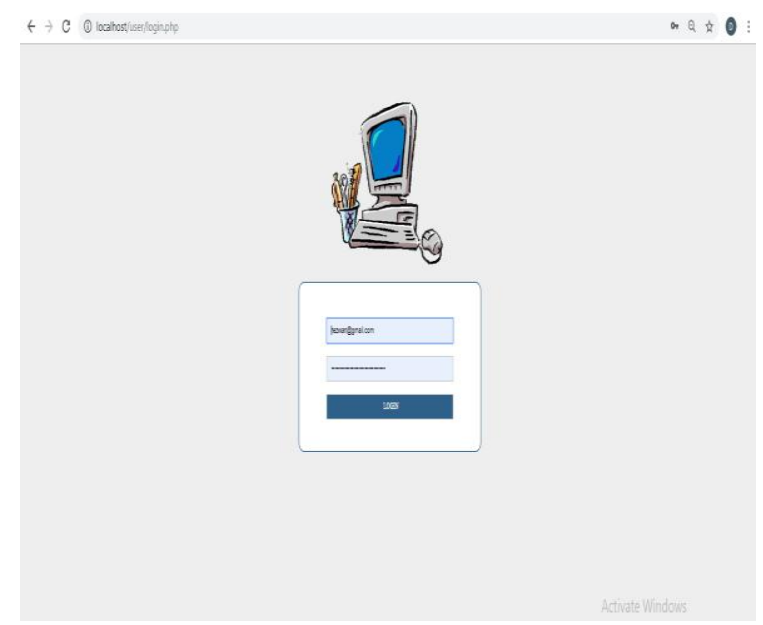

Gambar 5. Tampilan login

\section{Tampilan Beranda}

Pada halaman ini user diberi informasi mengenai pemilihan dan aplikasi menjelaskan tentang himpunan mahasiswa dan kinerja himpunan mahasiswa. Dapat dilihat pada gambar 8 .

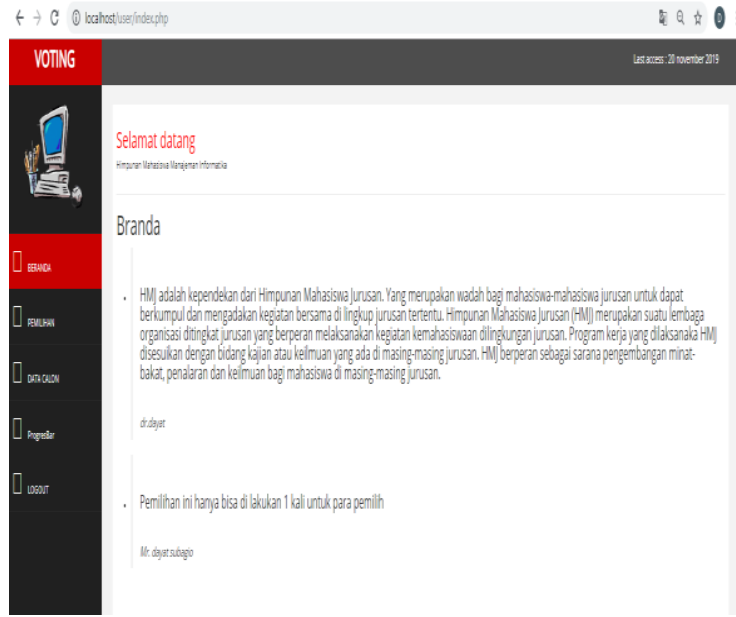

Gambar 6. Tampilan Beranda

\section{Tampilan Pemilih}

Pada halaman pemilihan user dapat memilih pasangan calon yang dipilih, pada from ini user harus menekan buton pasangan terlebih dahulu kemudian klik buton kirim agar data pemilihanya berhasil tersimpan didatabase, jika user hanya menekan button kirim maka aplikasi akan menyarankan untuk memilih pasangan terlebih dahulu. Pada from ini user hanya mampu memilih pasangan hanya sekali ketika user telah memilih pasangan calonya maka user otomatis logout dari Aplikasi . ketika user yang sama memaksa untuk masuk maka Aplikasi akan membawa pada tampilan progresbar untuk melihat hasil polling untuk sementara agar user mengetahui siapa kah pasangan yang saat ini unggul. Dapat dilihat pada gambar 9.

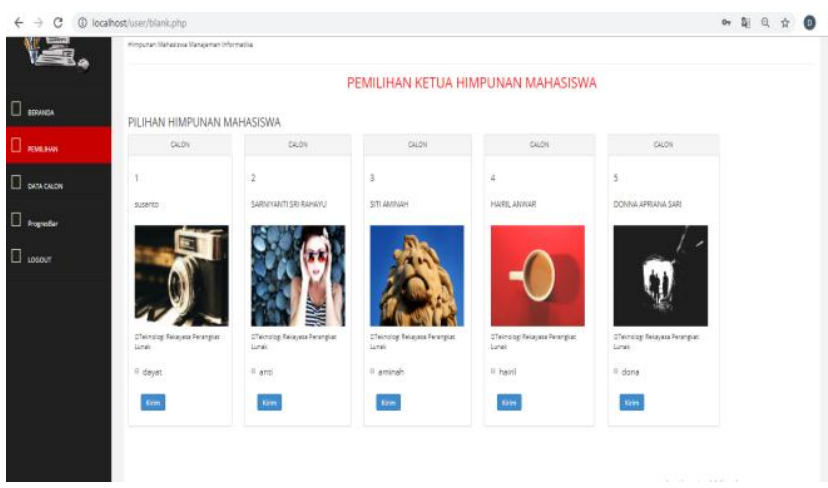

Gambar 7. Tampilan Pemilihan

\section{Tampilan Data Calon}

Pada tampilan Data Calon , user diajak untuk melihat visi dan misi calon, untuk memastikan apakah benar visi dan misi nya dengan yang ada dimasa kampanye dan ditampilan ini Aplikasi menampilkan juga foto dan nama dari calon agar pemilih dapat mengenalin dan mengetahui calon.Dapat dilihat pada gambar 10 . 


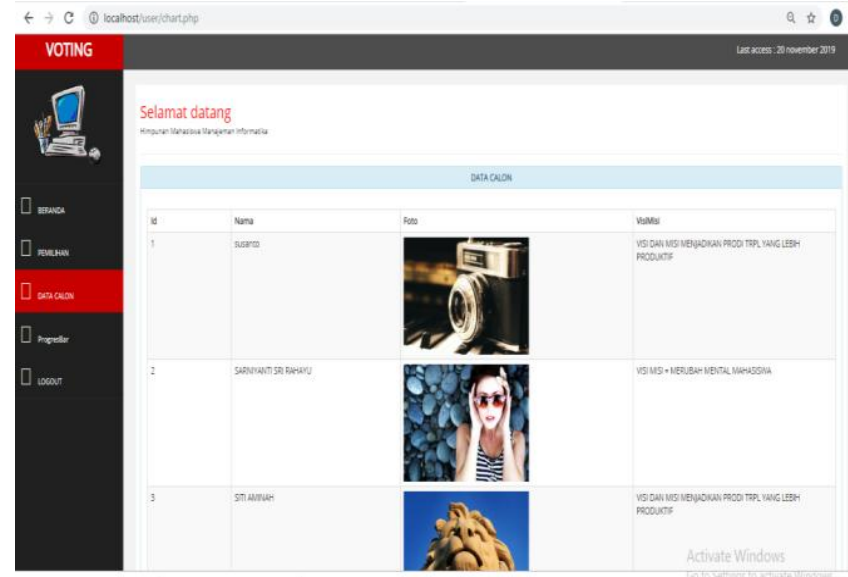

Gambar 10 Tampilan Data Calon

\section{Tampilan Progresbar}

Pada tampilan Progresbar, Aplikasi memberikan informasi berupa batang bar untuk pengguna agar user mengetahui bagaimana hasil dari pemilihan ketua himpunan mahasiswa tersebut. Agar pemilihan berjalan dengan terbuka dengan adanya publikasi perolehan suara tersebut. Dapat dilihat pada gambar 11.

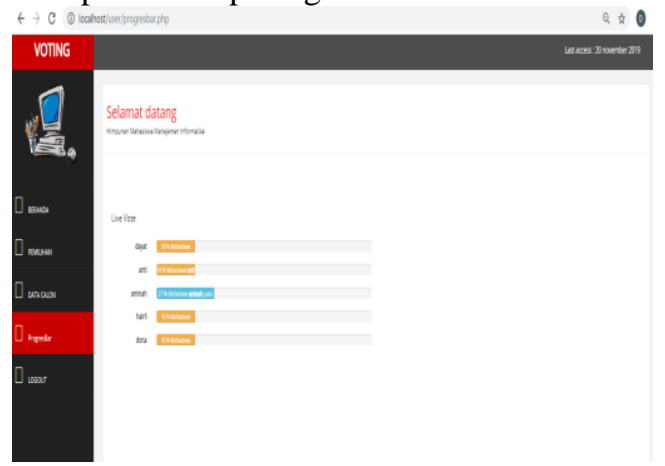

Gambar 8. Tampilan Progresbar

\section{Tampilan Admin Tambah Data Calon}

Pada Tampilan Data Calon, admin dipermudah untuk menambahkan data calon dengan menekan button Tambah Data Calon, didalam tampilan Aplikasi meminta agar user memasukan id, nama, foto, visi-misi, dan value. Ketika telah dimasukan dengan benar maka tampilan user akan bertambah sesuai data yang diinputkan oleh admin. Dapat dilihat pada gambar 13.

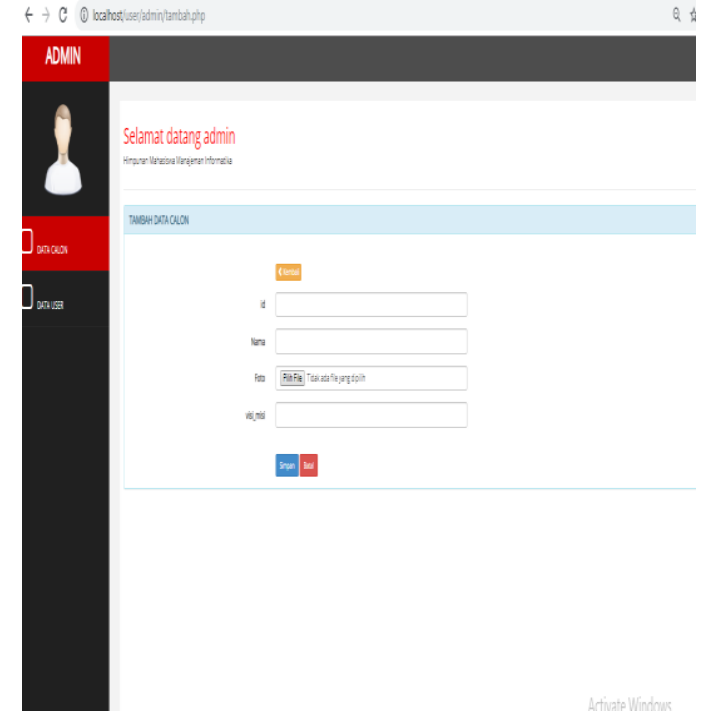

Gambar 13 Input Data Calon

\section{Tampilan Admin Data Login}

Halaman ini untuk melakukan update data, admin dapat mengudate data yang ada dengan cara memasukan lokasi reklame yaitu latitude dan longitude serta memasukan keterangan, alamat dan kategori reklame setelah selesai maka admin menekan tombol simpan dan data tersebut akan timbul dihalaman data reklame yang dapat dlihat pada gambar 14 .

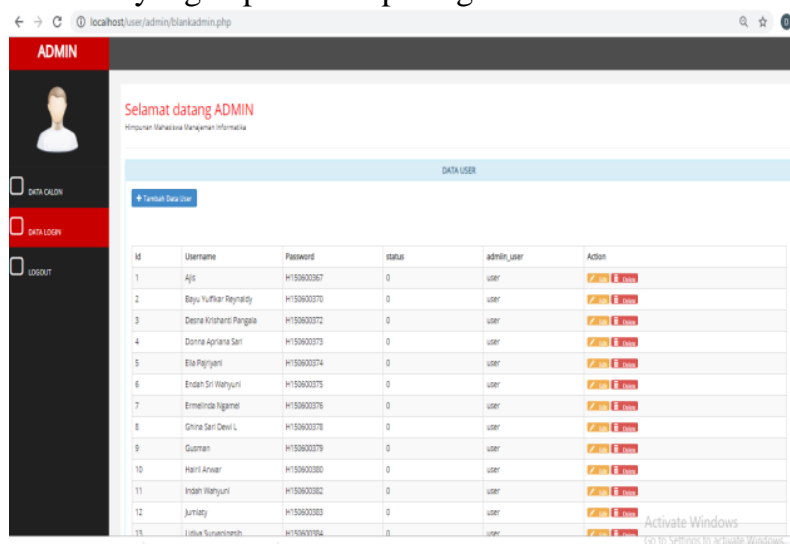

Gambar 14 Admin Data Login 


\section{B. Hasil Pengujian}

Berdasarkan dari Tabel 5 menyatakan tanggapan responden sebanyak 10 orang (Mahasiswa Akhir) dari hasil uji coba mengenai Aplikasi Perancangan Sistem EVoting Berbasis Web Untuk Ketua Himpunan Mahasiswa Teknologi Rekayasa Perangkat Lunak ini memiliki nilai yang tertinggi $78 \%$ dengan jawaban Sangat Setuju (SS).

Tabel 5. Hasil Pengujian Aplikasi

\begin{tabular}{|c|c|c|c|c|c|}
\hline \multirow{2}{*}{ No } & \multirow{2}{*}{ Pertanyaan } & \multicolumn{4}{|l|}{ Nilai } \\
\hline & & ss & s & KS & is \\
\hline 1 & $\begin{array}{l}\text { Apakah anda tertarik untuk menggunakan Aplikasi } \\
\text { Perancangan Sistem e-Voting Berbasis Web } \\
\text { Untuk Ketua Himpunan Mahasiswa Teknologi } \\
\text { Rekayasa Perangkat Lunak ini? }\end{array}$ & $19 \%$ & $80 \%$ & $0 \%$ & $10 \%$ \\
\hline 2 & $\begin{array}{l}\text { Apakah tampilan Aplikasi Aplikasi Perancangan } \\
\text { Sistem e-Voting Berbasis Web Untuk Ketua } \\
\text { Himpunan Mahasiswa Teknologi Rekayasa } \\
\text { Perangkat Lunak ini menarik? }\end{array}$ & $10 \%$ & $80 \%$ & $0 \%$ & $10 \%$ \\
\hline 3 & $\begin{array}{l}\text { Apakah Aplikasi Perancangan Sistem e-Voting } \\
\text { Berbasis Web Untuk Ketua Himpunan Mahasiswa } \\
\text { Teknologi Rekayasa Perangkat Lunak mudah } \\
\text { digunakan? }\end{array}$ & $20 \%$ & $70 \%$ & $10 \%$ & $0 \%$ \\
\hline 4 & $\begin{array}{l}\text { Apakah tampilan pada Aplikasi Perancangan } \\
\text { Sistem e-Voting Berbasis Web Untuk Ketua } \\
\text { Himpunan Mahasiswa Teknologi Rekayasa } \\
\text { Perangkat Lunak ini sudah sesuai dengan } \\
\text { kebutuhan? }\end{array}$ & $20 \%$ & $70 \%$ & $10 \%$ & $0 \%$ \\
\hline 5 & $\begin{array}{l}\text { ApakahAplikasi Aplikasi Perancangan Sistem e- } \\
\text { Voting Berbasis Web Untuk Ketua Himpunan } \\
\text { Mahasiswa Teknologi Rekayasa Perangkat Lunak } \\
\text { dapat membantu anda dalam Remilhan? }\end{array}$ & $0 \%$ & $90 \%$ & $10 \%$ & $0 \%$ \\
\hline & Rata-rata & $12 \%$ & $78 \%$ & $6 \%$ & $4 \%$ \\
\hline
\end{tabular}

\section{KESIMPULAN}

Berdasarkan dari hasil penelitian dan analisis yang telah dilakukan diperoleh kesimpulan sebagai berikut :

Dari hasil penelitian yang dilakukan terdapat pencapaian membangun aplikasi e-Voting dengan pengimplementasi dari pencapaian ilmu dibangku perkuliahan yang telah didapatkan, sistem ini berguna untuk memilih pasangan calon Ketua Himpunan Mahasiswa Teknologi Rekayasa Perangkat Lunak.

Aplikasi sistem e-Voting dapat mempermudah mahasiswa dalam memilih pasangan calon Himpunan Mahasiswa Teknologi Rekayasa Perangkat Lunak, memilih secara online tanpa harus menggunakan metode konvensional yang selama ini dilakukan.

Adapun saran saran pada Penelitian Sistem eVvoting Pemilihan Ketua Himpunan Mahasiswa Teknologi Rekayasa Perangkat Lunak Berbasis Web masih memiliki kekurangan. Berikut saran untuk aplikasi adalah sebagai berikut:

Pada Penelitian selanjutnya diharapkan aplikasi eVoting Pemilihan Ketua Himpunan Mahasiswa Teknologi Rekayasa Perangkat Lunak, diimplementasikan dengan teknologi android.

Pada Sistem e-Voting ini diharapkan kedepannya mampu membuat timer waktu agar setiap user yang belum mmemilih tidak dapat memilih karna waktu yang ditentukan telah habis.

Pada sistem e-Voting ini juga diharapkan kedepanya memiliki jumlah suara yang ditampilkan pada aplikasi e-Voting.

\section{DAFTAR PUSTAKA}

Azwanti, N. 2017, Perancangan E-Voting berbasis Web. http://jurnal.pcr.ac.id Web.

Effendi, I. pengertian domain. https://www.itjurnal.com/pengertian-domain-dan- hosting/.

Muis, $\quad$ A. $1990 \quad$ pengertian web. http://www.pintarkomputer.org/2015/10/pengertianweb-sejarah-web-dan-cara-kerja-web.html\# .

Murtado, A. 2011. Aplikasi pemilihan ketua Badan Eksekutif Mahasiswa STMIK Pontianak Berbasis Dekstop, Sekolah Tinggi Manajemen Informatika dan Komputer Pontianak Program Studi Teknik Informatika

Purwati, N. 2015. Perancangan Sistem E-Voting Untuk Pemilihan Kepala Daerah (Pilkada). AMIK BSI Jogjakarta

Salehudin, M. 2009 Pembuatan Model E-Voting Berbasis Web (Studi Kasus Pemilu Legislatif Dan Presiden Indonesia). INSTITUT TEKNOLOGI BANDUNG

salmadian .2018. pengertian demokrasi. https://salamadian.com/pengertian-demokrasi/.

Subhan, D. 2012. SISTEM E-VOTING BERBASIS WEB. Universitas islam negri gunung djati bandung

Zakaria, M. Pengertian Internet .https://www.nesabamedia.com/pengertianfungsi-dan-manfaat-internet-lengkap/. 